\title{
The Influence of Economic Growth on the Degree of Autonomy of the Regions and the Absorption of Labor and Social Welfare: Regencies and Cities of Maluku Province
}

\author{
Nahu Daud ${ }^{1}$ \\ ${ }^{1}$ Economic Studies Program, University Khairun Ternate of Indonesia, Indonesia \\ Correspondence: Priyono, Educational Technology Graduate Program, University of PGRI Adi Buana Surabaya, \\ Indonesia, Dukuh Menanggal XII Surabaya, Indonesia. Tel: 62-812-1697-4878. E-mail: \\ priyono.unu_sidoarjo@yahoo.com
}

Received: December 1, 2015

Accepted: December 17, $2015 \quad$ Online Published: January 25, 2016

doi:10.5539/ijef.v8n2p234

URL: http://dx.doi.org/10.5539/ijef.v8n2p234

\begin{abstract}
This research aims (1) to analyze and test the influence of economic growth on the degree of autonomy the area in County Government and city of Maluku Province, (2) Analyze and test the influence of economic growth on the absorption of labor on County Government and city of Maluku province (3) Analyze and test the influence of economic growth on the welfare of society at the County Government and the city of Maluku province (4) Analyze and test the influence of degree of autonomous region of absorption of labor on County Government and city of Maluku province, (5) Analyze and test the influence of the degree of autonomy the area of social welfare in the Government District and the city of Maluku province (6) Analyze and test the influence of absorption of labor against the welfare of the community on County Government and City Maluku province. The approach used is the analysis of Path Analysis, intended to answer a relationship direct or indirect causal model has been developed on the basis of theoretical consideration of researchers and certain knowledge. In addition to the causal relationship is based on the data, also based on knowledge, the formulation of hypotheses and logical analysis, so that it can be called path analysis can be used to test a set of causal hypotheses as well as to interpret these relationships.

The results showed (1) economic growth positively and significantly influence the degree of autonomy of the region. These results lend support to the hypothesis of one stating that economic growth was a significant influence on the degree of autonomy of the region. (2) The influential economic growth positively and significantly to labor absorption. These results lend support to the hypothesis of two stating that the influential economic growth dramatically to labor absorption. (3) Economic growth positively and significantly influences the well-being of the community. These results provide support for the three hypotheses which state that the economic growth affects significantly to the well-being of society. (4) The degree of autonomy the positive and significant effect of absorption of labor. (5) The degree of autonomy to the region in a positive and significant effect on the welfare of society. (6) The positive impact of labor absorption and significantly to the well-being of society. (7) The results of the discussion to confirm that economic growth affectsconsiderably to the well-being of the community through the degree of autonomy of the regions and the absorption of labor. Significant influence occurs because the existence of a direct relationship with the role of the community.
\end{abstract}

Keywords: economic growth, regional autonomy and degree of absorption of labor and social welfare

\section{Introduction}

Monetary growth is an indicator of monetary macro can be used to assess the success of the economic development of a country or region during a given period. Indicators are identified by rising per capita income or a rise in output coupled with changes in the economic structure as well as changes in the structure of the use of labor. The change of economic structure shows the occurrence of changes in the composition or arrangement of economic sectors in the Gross Regional DomesticProduct (GRDP), and then these changes go hand in hand with changes in the proportion of use of labor in each sector.

Djojohadikusumo (1994, p. 6) points out that one of the successes of economic development is the increase in production, therefore the development process requires a change in the composition of production and changes 
in the pattern of development (appropriations) source of production among the sectors of economic activity, changes in institutional framework as a whole. This means that a transformation is a change in course of time was characterized by changes in the fiscalstructure, the change in economic activity as well as the cornerstone of the framework the economic makeup of the community is concerned. Relation to the thought, then in 1990, the United Nation Development Program (UNDP) introduced a concept of progress that is named Human Development. This concept of prioritizing the development goals is at the achievement of making a man as the focus of development (Human Centered Development). The achievement of these goals can be measured by the indicators of human development index (Human Development Index).

Rochaida (2005) The research results show that socio-economic welfare variables defined by dimensions (indicators) of numbers read writer of 0,928 , followed by the life expectancy of $(0,583)$ and income per capita amounted (0.001). Build on the results of such analysis, the literacy figures occupy the leading position as the main determinant of social economic welfare variables area. Read writes numbers are an indicator of the impact of the field of education. He said to get an indicator of the impact because the number reflects a community intervention. Community interventions may contain the provision of a means to school or teachers. It also increased educational participation schoolage.

Research (Aschauer, 2000) uses data 46 low and medium income countries with the 1970-1990 periods in analytical aspects of such acceptance, as well as the efficiency of government investments in magnitudes with variable external debt as a proxy of the total government debt. From the results of his estimation found that the increase in government investment is financed with foreign debt brought a negative impact on economic growth.

Empirical findings (Kim, 1997) about the role of the regional authorities towards the economic growth of the region, found that the role of local governments in the region's economic growth is expected to be very real. Then it is said that local tax and other receipts in addition to local tax and real adverse effect on the economic growth of the region, while the local government investment and consumption expenditure of local government have a real and positive impact is greater. As for the policy implications that are important are local governments continue to encourage increased investment in the region, autonomous region continued and the centralgovernment should transfer the source of large revenue to local governments.

Build on the dimensions of a life expectancy which is a second-order as a determinant of social welfare economics is also an indicator of the impact of health improvement. That talks about higher the life expectancy, the higher the level of health in the area. While the per capita income for is measuring the smallest dimension in social welfare society. These results have to mean that income per capita is not the main determinant of success increased socio-economic health. This is because per capita income measurements as an indicator of social welfare society has its own weakness do not take into account the actual situation, because most of the population receives real incomes far below the per capita income there is.

Empirical studies (Brata, 2004) from the local public sector investment, human development, and poverty, indicating that the variable expenses health education and provide a positive and significant impact on the level of human development (IPM). The larger the allocation of expenditures for the development of education and health are also increasingly good IPM are reached. Social spending not only provides benefits for human development, but also in the reduction of poverty levels. Never the less, the influence of human resources (HDI) against the level of poverty seems greater than the influence of social expenditures. It can be at once suggests that adequate allocation of social expenditure in development expenditures provides benefits that are more and more good for poverty reduction through improved quality of human beings.

Based on empirical studies conducted by researchers in the past there were a few similarities, especially regarding economic growth area, the degree of fiscal autonomy of the regions, the absorption of the workforce per sector of the economy, as well as social welfare society. In line with this thinking, (Smoke, 2001) stated that development as a liberation to gain extensive choices and is within the framework of human development; do not let the human sacrifice on behalf of all the programs that spur growth. "Human happiness cannot be evaluated only by economic growth". It further explained that the country/regions are supposed to focus on the real goal, namely, development of human potential, after all the success of economic development should be started based on the increasing level of non-citizens are illiterate and life expectancy rather than growth in production or income level.

The success of the development not only of economic growth rates measured from the marked by changes in the structure of GDP as well as the structure of absorption of labor, but it also has to be measured from the success raised the dignity and the dignity of the higher societybecause it needed a size that can be invoked as a reference for measuring the success of development. Human development is one of the indicators of progress that can be 
used. IPM is a step which is based on three components namely: per capita income, education and age of life expectancy. The per capita income is one of the principal determinants of the degree of economic prosperity of society because it is a measure of purchasing power. If people's income is decreasing then its impact on lowering purchasing power capability so that welfare will also decrease.

The problems faced by counties and cities in Maluku province during the years 2000 to 2010 new population life expectanciesincreased 49.6 years in 2000 to 62 years by 2020.2013 nationally an estimated life expectancy of residents of Indonesia's population and year 66,18 se 65,47 in Maluku province. That means an average population of Indonesia was only able to enjoy her life until at the age of 66 years and average population se Maluku province can only reach the age of 65 years. The figure takes into account the level of public health in each county and the city of Maluku province. The higher the degree of health which is an area the higher life expectancy achieved.

After he set up autonomy and decentralization in Indonesia in 1999 up to the present has not seen a significant improvement in standard of living and level of social welfare, which is reflected in the indicators of economic growth, the level of life expectancy, the number of poor population, and logging per capita. The results of empirical research Sasana (2009) related to the role of fiscal decentralization on economic performance at the district/city of Central Java province showed that decentralized fiscal effect was not significant and has a negative relationship with respect to the rate of economic growth in the County/city in Central Java. The results of the study indicated a different Akai and Sakatan (2005) in Japan that decentralized fiscal member contributed substantially to economic growth. Cultural factors and economic growth rates are changed to give different effects between countries towards the implementation of autonomy and decentralization in their respective countries.

Research (Martinez \& Robert, 2001) regarding fiscal decentralization and economic growth in the countries developing during the years 1975-2006 found that the enactment of the autonomy and decentralized in each developing country brings a unique consequence. Tax policy in the sector and as a function of income grant in the model analysis showed different results. The enforcement of a high tax on the local level could increase the income of the area in the short term but negatively impact the well-being of the community in the long term, because of the high tax burden.

Empirical evidence from the study (Akai \& Sakata, 2002) related to regional disparities and fiscal decentralization showed that decentralized fiscal imbalances between regions can increase because of the strength of the redistribution of income become unbalanced, which resulted in a gap between the higher areas. Fiscal decentralization as a commitment to reduce regional disparities, from the results of the analysis has not been strong evidence indicates in encouraging equitable development among regions.

Research results (Desai, Freinkman, \& Goldberg, 2005) of fiscal federalism in the rente (case in Russia) confirmed that the tax sharing arrangements play an important role in establishing incentives for local development and reform. The area faced a higher retention rate tends to be moreinterested in developing the local tax base and, as a result, they are more likely to improve the business environment in support of the inclusion of new business and corporate restructuring originality, excessive adverse fiscal centralization reforms and regional investment on the contrary. The study also proved that the influence of the expansion of the financial autonomy of the regions is not a uniform can be advantageous for local economies. The results showed that an increase in the level of tax retention has the most powerful effect on regional economic performance in areas that are relatively free from possible

Understanding the relationship between economic growth related to the degree of regional autonomy, economic growth affect the absorption of labor, economic growth affect the welfare of the community, the degree of autonomy the labor absorption of impact, the degree of autonomy of the effect on the welfare of society, and labor Absorption effect on the welfare of society at the County Government and the city of Maluku Province is currently becomes very important and urgent, which aspects influenced the research was done.

\section{Research Methods}

Research methods used to answer the problem formulation and achieving research objectives namely: path analysis. Destination path analysis, describe the direct and indirect consequence of a set of variables, variable causes, as against other variables, the variable result, Sarwono, (2007, pp. 2-5). This analysis is one of the options in order to study the dependency in the model and a method to explain whether there is a large set of data, examines the relationship between the causal models that researchers have been formulated, on the basis of theoretical considerations and specific knowledge. Form of causal relationship in this study, using a model is not simple, because there is a double role as a variable independent variable on a relationship, but being the 
dependent variable in another relationship. Form of a relationship like this needs analysis tools that are capable of simultaneously explain.

Path analysis to be the right choice, formulation of the model to perform tests regarding the influence of economic growth on the degree of autonomyof the Labor Absorption and as well as the welfare of the city and county people in Maluku province. A model of simultaneous equations was constructed, or also commonly referred to as the following structural model:

$$
\begin{gathered}
Y_{1}=P_{1} X+\varepsilon_{1} \\
Y_{2}=P_{2} X+P_{4} Y_{1}+\varepsilon_{2} \\
Y_{3}=P_{3} X+P_{5} Y_{1}+P_{6} Y_{2}+\varepsilon_{3}
\end{gathered}
$$

\section{Results and Discussion}

\subsection{Analysis Results}

\subsubsection{The Influence of Economic Growth on the Degree of Autonomous Region}

Based on the results of the analysis,it shows that economic growth was positive and significant effect on the degree of autonomy of the region. This is evident from the line marked with a positive coefficient which is equal to the value of $0,680 \mathrm{c}$. $\mathrm{R}$ of 5,721 and significance probability (p) of the smaller than 0,000 level of significance $(\alpha)$ specified by 0.05 . This indicates that one hypothesis stating "influential economic growth positively and significantly to the degree of autonomy of the country and the city of Maluku province acceptable", because it proved to be the truth. These results indicate that the higher economic growth in the area. it will be the higher the degree of autonomous regions.

\subsubsection{The Influence of Economic Growth on the Absorption of Labor}

Results of the analysis show that economic growth was a good thing and significant effect of absorption of labor. This is efident from the line marked with a positive coefficient of 0,359 with a value of $R$ \$2,137 c. and acquired significance probability (p) of the smaller 0,039 of significance level $(\alpha)$ specified by 0.05 . This shows that the two hypothesis that state "influential economic growth positively and significantly to labor absorption of regencies and cities of Maluku province are acceptable", because it proved to be the truth. These results indicate that the higher economic growth in the area.it will be the higher labor absorption.

\subsubsection{The Influence of Economic Growth on the Welfare of Society}

Based on the results of the analysis showed that the influence of economic growth on social welfare has coefficients of 0,239 lines with value $\mathrm{C}$ r. of 2,048 and significance probability (p) of the smaller 0,048 of significance level $(\alpha)$ specified by 0.05 . This suggests that the three hypothesis which state that economic growth has a positive and significant impact on the welfare of the community district and the city of Maluku province acceptable. This shows that if the economic activities in the area of improved and strenghtened economic growth, the welfare society will increase anyway.

\subsubsection{The Influence of Degree of Autonomous Region of Absorption of Labor}

Job creation is a problem which is very essential because of the "multiplier effect" of his high. Employment related to self-esteem and dignity. Based on that concept then the according calculation result shows that the influence of the degree autonomous region of absorption of labor have value line marked with a positive coefficient of 0,362 with a value of $\mathrm{R} \$ 2,153 \mathrm{c}$. and acquired significance probability (p) of 0,038 is smaller than the alpha $(\alpha)=0.05$. This shows that the four hypothesis state that the degree of autonomy the positive and significant effect of absorption of labor district and city Maluku province proved to be true and acceptable.

\subsubsection{The Influence of Degree of Autonomous Region against the Welfare of Society}

Based on the findings of the analysis results indicate that the influence of degree of autonomous region against the welfare of the community has a value line of 0,221 coefficients with a value of $\mathrm{C} \$ 1,968$. R and the level of probability of 0.049 are less than the alpha $(\alpha)=0.05$. This shows that the five hypothesis suggesting that the degree of autonomy the positive and significant effect on the welfare of the community district and city Maluku province proved to be true and acceptable.

\subsubsection{The Influence of Absorption of Labor against the Welfare of the Community}

From the results of the analysis indicate that the influence of absorption of labor against the welfare of society have value line coefficient of 0,537 with value C. $R \$ 4,985$ and significance probability ( $p$ ) of the smaller of 0.000 from alpha $(\alpha)=0.05$. This shows that the six hypothesis States that the absorption of labor has a positive 
and significant impact on the welfare of the community district and the city of Maluku province acceptable. These results indicate that the higher the absorption of labor, thus increasing the welfare of society. Vice versa, if the absorption of the smaller workforce then the welfare society will also be getting smaller. Increased prosperity can be indicated along with the increased income earned by workers.

\subsection{Discussion}

\subsubsection{The Influence of Economic Growth on the Degree of Autonomous Region}

Referring to the statistical results, it was found that the influence of economic growth on the degree of autonomous region showed that. Economic growth was positive and significant effect of the degree of autonomy of the County and the city of Maluku province, meaning the higher economic growth in the area, it will be the higher the degree of autonomous regions. These results are in accordance with research conducted by (Kim, 1997) in Korea about the role local governments against economic growth. The results of this study concluded that government investment (expenditure of development) and Government consumption expenditure (routine expenses) has a positive and significant impact on economic growth. An important policy implication is that local Government continues to encourage increased investment in the region, because it has a double effect (multiplier effect) towards the improvement of the welfare of the community and local government through the acceptance of the original Regional Revenue (PAD).

The results of this study also supports the opinion (Kirana, 2000, p. 72); (Mursinto, 2004); (Brata, 2004) that the Original Regional Revenue (PAD) is a type of reception area which is directly related to the role of the community, thus theoretically this kind of acceptance will continue to experience an increase in line with the development of the economic activities of the community. Economic activities can be reflected by the small number of large GDP. Study results (Miller \& Russek, 1997) about the relationship between the fiscal structure with economic growth in the United States concluded that the budgetary problems being faced, is the increased tax revenue on the one hand, and the lack of acceptance of the Government on the other side, and reduced government spending on the other side. Tax revenues can increase the revenue of the original area (own revenues), when the tax was used to build infrastructure, and it would be a negative impact if used for transfer payments.

The results of this study reinforce the opinion of Iswardono (1990, p. 17) that the GDP growth of an area affects the Native Revenue (PAD), because the bigger the GDP a region will be even greater as the PAD is expected to the area. This is certainly related to the potential of the area in support of production generated in the area. The presence of a supportive business climate and infrastructure will drive the rate of growth of GDP. Thus the double impact PAD, PAD to affect regional economic growth (GDP) and GDP impact PAD instead.

The results of this study support the empirical findings (Martinez \& Robert, 2001; Mahi, 2000; Dartanto \& Brodjonegoro, 2003; Kim a. Hyun, 2006) which explains that decentralization has a direct impact on the high economic growth when fiscal decentralization is centered on public spending/expenses. Fiscal decentralization as measured by regional government spending caused economic growth significantly in these areas. In an era of fiscal decentralization by transfer of funds from the Central Government authorities and the vast area to manage and optimize the economic potential of the potential that exists to give positive effects on regional economic growth

\subsubsection{The Influence of Economic Growth on the Absorption of Labor}

The economic growth of a region in General was indicated by changes in gross Regional domestic product (GRDP) from year to year. For local governments, the indicator is important to know the success achieved economic development and become a guideline in determining the direction of development in the future. The ever-increasing economic growth will expand employment opportunities in line with the development of the activities of each sector of the economy as the sector's primary, secondary and tertiary. Refer to statistics analysis results is in line with the findings of previous research (Ingram, 2000) which confirmation that the economic development in East Java, resulting in a relatively high economic growth, which is indicated by the rise in domestic output and value added. Economic growth is the means essential for further economic development, because in addition to encouraging the development of economic sectors also creates jobs. Economic growth also means more and more goods and services available domestically, and rising incomes push the high purchasing power of society is increasingly high. Studies conducted by Walterskirchen, (1999) in Europe prove that there is a positive relationship between economic growth and robust with change of employment opportunities. Furthermore he also discovered that there is a negative relationship between growth in employment with the unemployment rate, but not $1: 1$, which means that the speed of growth in employment opportunities is not equal to the speed of the decline in unemployment. 
Mazumdar (2003), studies in India, who observed the change an undeniable advantage of work related to changes in the level of wages. Mazumdar concludes that there is a trade-off between employment-growth with wage-growth, meaning if there is wage growth, the growth of employment opportunities declined and conversely if there is a decline in wages, then the job opportunities will increase. Choi (2007) using the job market equilibrium approach to determine the employment effect of economic growth. Choi found that elasticity of employment is determined by: i) the elasticity of labor supply with respect to real wages, ii) elasticity of the marginal product of labor, iii) elasticity of the marginal product of capital and output elasticity, iv) against the capital.

In contrast to previous research, Suryadarma et al. (2007) observed the effects of economic growth are distinguished into three main sectors, namely agriculture, industry and services, as well as changes in the level of participation work against the growth of employment opportunities, with the rural and urban areas of difference. By using the data panel provinces in Indonesia in 1987, 1990, 1993, 1996, 1999 and 2002, Suryadarma discovers that the growth of the occurred in the service sector in urban, agriculture and industrial sectors in the rural influence significantly to increased employment opportunities.

The above explanation of the confirmation two things: (i) economic growth can improve employment opportunities, which can further reduce unemployment, (ii) the growth rate of wages will reduce the growth of employment opportunities and wage decrease instead will increase employment opportunities.

\subsubsection{The Influence of Economic Growth to the Welfare of Society}

Results of statistical tests show that the influence of economic growth to social welfare has a path coefficient are positive and significant influence on the welfare of the community district and city Maluku province. The results of this research in line with his work (Rochaida, 2005) which shows that the socio-economic welfare variables are determined by the dimensions of the indicator numbers or read write of 0,928 , followed by the 0,583 of life expectancy and per capita income is equal to 0.001. Economic growth should provide more benefits to the poor and provides an opportunity to improve the situation of its economy, or economic growth that is pro poor growth. Pro poor growth with heavy points on equitable development, will fix the welfare and the distribution of income is more evenly distributed (equity aspects), in which this aspect will strengthen the impact of growth on poverty reduction (Nathaniel Dahlin, 2002 and 2004). Suharto, (2006) concluded that economic growth has yet to be pro poor growth during the period 2002-2005 and pro poor growth period 2005-2009. However, the degree of pro poor growth in provincial level be different from each other.

Economic development does not only aim at creating a growth as high as possible, but must also be able to reduce the level of inequality, and inequality of income distribution and improving the provision of employment. High economic growth and poverty reduction should be implemented simultaneously through a variety of economic development policy, so the whole element of the population can participate in that process, the poor population is no exception (Todaro\& Smith, 2006). Increasing the involvement of the poor can be done through improved human resources (education and health) and increased access to factors of production resources, so that economic growth is offset by the revenue equalization will encourage poverty reduction and creating prosperity.

\subsubsection{The Influence of Degree of Autonomous Region of Absorption of Labor}

Statistics show that the test results influence degree autonomous region of absorption of labor have value line marked with a positive coefficient. This indicates that the degree of autonomy the positive and significant effect of absorption of labor district and the city of Maluku province, Result is in line with the findings (Ingram, 2000), that economic growth is an important means for further economic development, because in addition to encouraging the development of economic sectors also create jobs. Then the results of this research are also in line with the results of a study (the one, 2004) stating that in line with the tasks that are run by local governments, in the long run increase the budgets are expected to provide a stimulant to the economic growth of the region. This condition is achieved when policies that made local governments can encourage the development of the corporate world. With the development of the economy of the region, the positive impact will also be enjoyed by local governments in the form of labor, increasing absorption PAD and so on.

Based on the fact, regional economic development requires cooperation between local government, private and community. This is in line with (Arsyad, 1999, p. 108; and Barzelay, 1991) that the development of the local economy is a process where there is cooperation between local governments, community groups, and the private sector set up to manage the resources that exist, to creating jobs and stimulating economic activity (economic growth) in the region. It further mentioned that the basic problem in economic development is located on the emphasis of development policies based on the idiosyncrasies of the region concerned (endogenous development) 
by using the potential of human resources, institutional, and physical resources locally (regions).

\subsubsection{The Influence of Degree of Autonomous Region Against the Welfare of Society}

In line with statistics analysis results indicate that the influence of degree of autonomous region against the welfare of society have coefficients are positive and significant influential lines of community welfare regencies and cities Maluku province. The results of this study are in line with studies (Brata, 2005) stating that Government spending in education and health care gives a positive and significant impact on the level of human development. This may indicate that the larger the allocation of expenditures for education and health development the better the good also the human development index (HDI) are reached.

The results of this study are supported by a study conducted by the (Word Bank, 2003) about the growth model of the ideal city and County, which is its emphasis on public service improvement efforts. That good governance will encourage the provision of the service of the district and the city are high-quality, so that investors will be attracted to the progress so as to stimulate regional economic development and improve the quality of life for all people, including the poor. Then the results of this study supports the results of a study $(1982,1999)$ about economic growth between regions (local) in the United States stated that in terms of the relationship between local government budget policy with the local economic growth showed that the growth of the local economy along period observed correlated positively with the local government expenditures for primary education and secondary education.

The results of this study support the opinion (Halim, 2004, p. 22. Prints, 2002, p. 8; Cherniavskii \& Vartapetov, 2005; Musgrave \& Musgrave, 1991, pp. 6-13) stated that the main characteristic which indicates an autonomous region is able to autonomy that is located on the financial capability of the region. This means that the autonomous region must have the authority and ability to dig its own financial resources, managing and using its own finances is enough to finance the inaugural Government regions. Dependence of intensity as minimum as possible should help center, and it is expected that the original area of Revenue (PAD) should be the biggest part in mobilizing and organizing of local government and regional development.

\subsubsection{The Influence of Absorption of Labor against the Welfare of Society}

Statistical analysis of results showed that the influence of absorption of labor against the welfare of the community have a positive path coefficient value and significantly to the well-being of the community district and city se Maluku province. This suggests that the higher labor absorption, thus increasing the welfare of society. Vice versa, if the absorption of the smaller workforce then the welfare society will also be getting smaller. Increased prosperity can be indicated along with the increased income earned by workers. The results of this study support the view (Muhammad, 2004; Todaro, 2004, p. 280; Sumodiningrat, 2001, p. 13) that the greater and varied economic activity in a community, certainly it is good because it will create jobs. Employment income, and would give the earnings of that person and their families meet the needs of his life, especially the basic necessities: food, clothing, Board, medical care, and education.

Theoretically the demand of employers over labor, because someone's help for the production of goods and services for sale to the public consumers (users). Thus, the increase of the demand of employers is against labor.depending on the demand of the community of goods that it manufactures. In line with such things (Jackson Bellante, 1990, p. 25) explains that demand for labor was the relationship between the level of wages and labor quantity desired by employers to be employed in particular. In addition the company will request function based on labor with the assumption that every manufacturer is always trying to maximize profit, then the basis of the considerations used someone entrepreneurs to increase or decrease the amount of labor is when marginal revenue is greater than marginal cost. This will continue as long as marginal revenue is greater than the wages given to labor (marginal cost), meaning labor demand will occur when the demand for goods and services increases or marginal revenue entrepreneurs greater than marginal cost.

work force to the development policy implications that need to be implemented, should be prioritized on expanding employment opportunities. With the expansion of employment opportunities are expected to increase productivity and income of workers.

\section{Conclusion}

1). Economic growth positively and significantly affects the degree of autonomy of the region. These results provide support for the increase in economic growth will lead to a rise in the degree of autonomy of the region.

2). Economic growth impact positively and significantly to labor absorption, which implies an increase in economic growth will lead to increased absorption of labor. 
3). Economic growth positively and significantly affects the well-being of the community. It means economic growth will improve the welfare of society.

4). The degree of Autonomy is the positive and significant effect of absorption of labor. These results suggest that an increase in the degree of autonomy to the region will increase the absorption of labor.

5). The degree of autonomy the area is in a positive and significant effect on the welfare of society. These results give meaning that the increase in the degree of autonomy the area will improve the welfare of society.

6). Labor absorption effect positively and significantly to the welfare of society, which have implications for the labor and absorption will improve the welfare of society.

7). Theresults of this study are important to the Government as a material consideration in formulating policies that could encourage the development of the corporate world in the effort of local economic development. With the development of the economy of the region, it will provide a positive impact both on local governments in the form of absorption of labor as well as increase revenue (PAD) Native, all of which would improve the welfare of society comes down to.

\section{References}

Akai, \& Sakata. (2002). Fiscal decentralization contributes to economic growth: Evidence from state-level cross-section data for the United States. Journal of Urban Economics, 52(2002), 93-108.

Akai, \& Sakata. (2005). Fiscal Decentralization, Commitment and Regional Inequality: Evience of from State-level Cross-sectional Data for the United States. CIRJE Discussion Papers. Retrieved from http://www.e.u-tokyo.ac.jp/cirje/research/03research02dp.html

Anonymous. (2004). Portrait of the economy of the area before and the Era of decentralization. Potpourri research results 2004.

Arsyad, L. (1999). Introduction to the Planning and economic development District. Yogyakarta: BPFE.

Aschauer. (2000). Public Capital and Economic Growth: Issues of Quantity, Finance, Economics and Efficiency. Development and Cultural Change Journal, 48(2), 391-406.

Bahl, R. (2000). China: Evaluating the Impact of Intergovernmental Fiscal Reform in Fiscal Decentralization in Developing Countries. In Richard (Ed.), Bird and Francois Vaillancourt. United Kingdom: Cambridge University Press.

Barzelay. (1991). Managing Local Development. Lessons From Spain. Policy Science Journal, 23(3), 271-290.

Baskaran., L. (2009). Decentralization and Economic Growth in OECD Countries: Is there a Relationship? Cesifo working paper No. 2721 category 1: public finance

Bellante, D., \& Mark, J. (1990). Economy Employment. Translation Wimandjaya K. Liotohe, Jakarta: Institution Publishers 1993.

Cherniavskii, \& Vartapetov, K. (2005). Fiscal Decentralization and Local Governmet in the Reform Period. The Journal, 47(11), 18-36.

Choi, C. K. (2007). The Employment effect of economic growth: Identifying determinants of employment elasticity. Chonbuk National University, October.

Evidence from Russia. (2005). Journal of Comparative Economics, 33, 814-834. Retrieved from http://www.elsevier.com/locate/jce

Gunandi, B. (2004). The composition of the acceptance of the public sector and Regional economic growth in Indonesia. The Economic Journal, 13(20), 59-71.

Gunawan, S. (2001). The Government's Response To The Economic Gap responsive: Empirical Study On Jakarta. Wisdom and Development Program within the framework of community empowerment.

Hadi, S. (2000). Linkages between the sector and the factors that affect the performance of the economy and income distribution in East Java, Surabaya. Dissertation: PPS Airlangga University.

Halim, A. (2004). Bungah Potpourri Financial Management Areas. Yogyakarta: UPP YKPN.

Khusaini, M. (2006). Public economics: Fiscal Decentralization and regional development. poor: BPFE Unbraw.

Kim, H. S. A. (2006). Desentralization and Economic Groeth in Korea. Korea Institution of Public Finance. 97-6, Garak-Dong Songpa, Seoul Go 238-774. 
Kim, S. T. (1997). The Rule of the Local Public Sector In Regional Economic Growt In Korea. Asian Economic Journal, 11(21), 166-168.

Mar'ie, M. (2004). Jakarta: Indonesia's human development in Essence, Koran Tempo.

Martinez-Vasquez, J., \& Robert, M. (2001). Fiscal Decentralization and Economic Growth. International Studies Program Working Paper. Atlanta: Andre Young School of Policy Studies, Georgia State University.

Mazumdak, D., \& Sandip, S. (2007). The Employment elasticity in organized manufacturing in India. Munk Centre for International Studies University of Toronto, Canada, July, Mahi Raksaka, 2001. The prospect of Decentralization in Indonesia in terms of Equity Between regions and increased efficiency. Analysis of CSIS, XXIX, 54-66. Jakarta: Indonesia Project, Jakarta.

Musgrave, R., \& Peggy, B. M. (1991). The State finance in theory and practice. London: Eason.

Nathaniel, D. B. (2002). The Impact of Education on Economic Growth, Theory, Finding, and Policy Implications. Papers, Duke University.

Oates, W. (1993). Fiscal Decentralization and Economic Development. National Tax Journal, XLVI, 237-243.

Prints, M. (2002). Format of financial ties to the Central Government and regions refers to the achievement of National Goals. National Seminar on "Public Sector Scorecard, Jakarta, 17-18 April 2002.

Raj, M. D., Lev, F., \& Itzhak, G. (2005). Fiscal federalism in rentier regions.

Rizwanul, I. (2004). The Nexus of Economic Growth, Employment and Poverty Reduction: An Empirical Analysis. Issues in Employment and Poverty, Discussion Paper Recovery and Reconstruction Department International Labor Office, Geneva, January.

Rochaida, E. (2005). The influence of regional development Disparity Of Labor Absorption Structure and socio-economic well-being of the communities in the area of East Kalimantan. Dissertation, University of Airlangga in Surabaya: PPS.

Sasana, H. (2009). Role of Fiscal Decentralization Against Economic Performance In District/City Province Central Java. Journal of Development Economics, 10(1), 103-124.

Smoke, P. (2001). Fiscal Decentralization in East and Southern Africa. New York: New York University.

Sumitro, D. (1994). The development of economic thought: The basic economic theories of economic growth and development. Jakarta: LP3ES.

Tao, Z., \& Heng-Fu, Z. (1998). Fiscal Decentralization, Public Spending and Economic Growth in China. Journal of Public Economics, 67, 221-240.

World Bank. (2003). Cities in Transition, Urban Sector Overview In the Decentralized Indonesia. Working Paper $\# 7$.

\section{Copyrights}

Copyright for this article is retained by the author(s), with first publication rights granted to the journal.

This is an open-access article distributed under the terms and conditions of the Creative Commons Attribution license (http://creativecommons.org/licenses/by/3.0/). 